\title{
Geochemical and SHRIMP U-Pb zircon chronological constraints on the Magam-mixing event in eastern Kunlun orogenic belt, China
}

\author{
Chengdong Liut‡*, Xuanxue Mot, Zhaohua Luot, Xuehui Yut, Shuwei Li† and Xin Zhaot \\ † China University of Geosciences, Beijing, 100083, CHINA \\ ‡ East China Institute of Technology, Fuzhou city, Jiangxi province, 344000, CHINA \\ *To whom correspondence should be addressed. E-mail: chdliu@ecit.edu.cn /edliu@ecgi.jx.cn
}

A spectacular east-west extending granitoid belt in the Eastern Kunlun Orogeny, China is about $800 \mathrm{~km}$ long by $40-80 \mathrm{~km}$ wide and composed of many complex plutons, which contain abundant mafic microgranular enclaves (MME). The late Paleozoic- early Mesozoic granites are prevelent in thegranitoid belt. As one of thetypical plutons, Yugelu pluton with an area of about $100 \mathrm{~km}^{2}$ situated at about $30 \mathrm{~km}$ southeast from Xiangride town of Qinghai province.

The pluton constitutes a magma series that ranges from hornblende-gabbro, diorite, granodiorite to monzogranite, and minor syenogranite etc.with dominance of granodiorite. MME arewidely distributed in granodioriteand are only a few in others. The abundance of MME in the granites of Yuegelu pluton in the most felsic body is less than $0.5 \%$, whereas in the most mafic one is up to $10 \%$. Most MME are well-defined and have a sharp contact with diffused boundary. The enclave sizes range from less than $1 \mathrm{~cm}$ to more than $2 \mathrm{~m}$ in diameter, a few even up to 5 $\mathrm{m}$, but most of them are in the range of 10 to $50 \mathrm{~cm}$. The various shapes of MME, such as spheroidal, ellipsoidal, banded, wedgeshaped and irregular onesare commonly observed and show the streamlined shape with the features of rheology. These features provide a convincing evidence that they result from magma mingling (Chengdong Liu et al. 2002).

All MME show igneous texture, and are commonly porphyritic, with plagioclase, hornblendeand biotiteoccurring both as phenocrysts and in the groundmass. Flow structures are occasionally developed with hornblendes underling linear flow structure. Structure of this type may result from plastic flowage under high-temperature conditions (Didier et al. 1991). Moreover, quenched rims, acicular apatites, irregular overgrowth of plagioclase, mantled quartz ocelli have frequently been seen within them. All of these evidences imply that MME are formed by magma mingling process (Vernon 1983).

The mineral assemblage of MME is plagioclase, hornblende, quartz, and subordinate biotite and K-feldspar. Accessory phases include zircon, titanite, apatite, magnetite, ilmenite and hematite. Plagioclases range widely from An8 to An87, but most from An35 to An55. Analyses of amphiboles by EPMA reveal that the enclaves have mainly magnesiahornblende compositions, with ratio of $\mathrm{Mg} /(\mathrm{Mg}+\mathrm{Fe})$ between 0.48 and 0.50 , similar to those found in their host rocks.

Major, REE and trace elements were investigated in the Central Laboratory of Hubei Geological Bureau using conventional chemical analysis techniques, ICP and atomic absorption spectrometry respectively. Major element abundances in MME indicatethat they are mostly intermediate in terms of $\mathrm{SiO}_{2}$ content from $52.13 \%$ to $62.4 \%$. Together with their host rocks, they belong to calc-alkaline, weakly peraluminous series, reflectinga subduction environment. Abundancesofmany elements of rocks show good linear variation on Harker diagrams, which indicate magama mixing origin (Chappell 1996).

¿REE of MME are from 111.87 to 197.03 ppm, and those of their host rocks range more widely from 66.68 to $226.85 \mathrm{ppm}$. Moreover, $\Sigma$ REE abundances of MME are slightly higher than their host rocks. Chondrite-normalized REE patterns for MME are generally similar to those of the host granites. Both have a LREE enrichment $\left((\mathrm{La} / \mathrm{Yb})_{\mathrm{N}}=1.04-34.80\right)$ and a slight negativeEuanomaly.

The trace elements in both MME and their host granites are characterized by a slightly high abundance of $\mathrm{Rb}, \mathrm{Th}, \mathrm{Zr}, \mathrm{Y}$ and low $\mathrm{Ba}, \mathrm{Nb}, \mathrm{Sr}$, Ti. This feature reflects that MME and their host granites are in one hybrid series.

Isotope data of $\mathrm{Sm}, \mathrm{Nd}, \mathrm{Rb}$ and $\mathrm{Sr}$ were determined byVG354 in Solid Isotope Laboratory of Institute of Geology and Geophysics Chinese Academy of Sciences. Isotopic data from MME have initial ${ }^{87} \mathrm{Sr} /{ }^{86} \mathrm{Sr}$ from 0.70859 to 0.70956 , and those of their host granites arefrom 0.70144 to 0.70972; and $\varepsilon N d$ in MME from -4.5 to -9.2 , and in host rocks from -5 to -6.2 .These data are roughly similar.

Single-grain zircon $\mathrm{U}-\mathrm{Pb}$ dating for $\mathrm{MME}$, host granodiorite, and related hornblende-gabbro have been conducted in Beijing SHRIMP Center by using SHRIMP II and yielded $241 \pm 5 \mathrm{Ma}, 242 \pm 6 \mathrm{Ma}$ and $239 \pm 6 \mathrm{Ma}$ of ages, respectively. The results indicate that the three types of rocks were formed almost in the same event

All these data imply that the granites have the origin of magma mixing. The mixing/ mingling event between the crustand mantle-derived magmas prevailed in the early-middle Triassic epoch in Eastern Kunlun orogeny. And thegranitoid host rock and hornblende-gabbro may approximately represent the acid and basic end-members of themixing with theratio of about $70 \%$ and $30 \%$ estimated by $\mathrm{SiO}_{2}$, respectively. MME are the incompletely mixed clots of the basic magma injected into the acid magma. Consequently, theinjection and reaction of mantle mass and energy into/ with the crust play an important role in the origin of granites and the vertical growth of the crust.

\section{References}

Chengdong Liu et al. 2002.Characteristicsand origin of mafic microgranular enclaves in Yuegelu granitic pluton in Eastern Kunlun. Geol Bull China. 739-744

Didier J and B Barbarin. 1991. Enclaves and Granite Petrology. Elsevier. Amsterdam. 625p

Vernon RH 1983. Restite, xenoliths and microgranitoid enclaves in granites. J Proc R Soc N SW 77-103

Chappell BW. 1996. Magma mixing and the production of compositional variation within granite suites: evidence from the granites of southeastern Australia.J Petrol. p 449-470

Compston W et al. 1992. Zircon U-P ages of early Cabbrian time-scale. J Geol Soc 171-184 